\title{
Prevalence of food allergies among Vilnius city primary school children
}

\author{
Andrius Kavaliūnas*, \\ Genè Šurkienė, \\ Rūta Dubakienè, \\ Kęstutis Žagminas,

\section{Rimantas Stukas} \\ Institute of Public Health, \\ Faculty of Medicine, \\ Vilnius University, \\ M. K. Čiurlionio 21, \\ LT-03101 Vilnius, \\ Lithuania
}

The aim of this research was to evaluate the prevalence and pattern of food allergies among primary schoolchildren in Vilnius, Lithuania.

Methods. Vilnius University was a partner in EuroPrevall integrated project - "The prevalence cost and basis of food allergy in Europe", which is an EU-funded multi-disciplinary research study. By implementing this project, using an anonymous questionnaire, 3084 (5-12 year old) schoolchildren of the 1st-4th grade from primary schools in Vilnius were investigated.

Results. $46.9 \%$ of 5-12 of children from primary schools had a self-reported illness or trouble caused by eating a food or foods; boys and girls were affected similarly. Food allergy was diagnosed by a doctor to $16.4 \%$ of schoolchildren. After analyzing children, who had trouble after eating, we discovered that the biggest group was among 9-year old ones (26.8\%); and a smaller one among 7, 8 and 10-year old schoolchildren (26.0; 22.2 and $19.6 \%$, respectively), the majority of them suffered from diarrhoea and vomiting (48.0\%). Rash, nettle sting like rash or itchy skin were also frequent symptoms (46.4\%). Other common symptoms were headaches (17.6\%) and a runny or stuffy nose (16.8\%). Fruit (24.6\%) and mostly citrus (7.8\%) was the most common food that caused clinical symptoms. Other important, problematic foods were milk and dairy products (19.4\%), chocolate (10.9\%), eggs (7.4\%).

Conclusions. According to the results of our research, almost half of the children of the primary schools in Vilnius had a self-reported illness or trouble, caused by eating. This shows us that food allergy might be a serious problem among schoolchildren in Vilnius; therefore it is essential to continue the research on food allergies, in order to find out tools and information necessary for policy makers, regulators, clinicians and allergic consumers, together with the food industry to effectively manage food allergies and the allergens causing them.

Key words: food hypersensitivity, food allergy, prevalence, schoolchildren

\section{INTRODUCTION}

Allergies are an increasing health disorder among children and adults in all over the world, although the clinical variety and variability as well as the causes of the increasing prevalence of these diseases are still little explored. Continual in-

\footnotetext{
*Corresponding author. E-mail: andrius.kavaliunas@gmail.com
}

The paper was presented at the 5th International conference "Vital Nature Sign", Kaunas, Lithuania, May 19-21, 2011. crease of allergies over the last three decades is associated with the environmental pollution, daily use of chemical agents and western lifestyle [1]. Food allergy, from which children often suffer, has a significant medical, financial and social influence not only on children themselves but also on their families. The whole world is seriously concerned about a great economical loss caused by allergies. Allergy influences the society because of the direct expenses for health care, hospitalization, medicine, to add the indirect cost of missed lessons in school and working hours in parents' jobs 
that decreases the family revenue and work efficiency. Thus, the treatment and prevention of allergies is one the main challenges of the modern public health, science and medical community [2].

According to the research data, the prevalence of food allergies in industrial countries constantly increases and involves $6.0 \%$ of children and $3.0-4.0 \%$ of the adults' population $[3,4]$. Although it is known, that the frequency of food allergies varies, the estimations of prevalence are not unified, and therefore it is hard to compare the prevalence between countries and even between the surveys. A metaanalysis of many studies has shown that prevalence of food allergies may vary between 3.0 to $35.0 \%$ [5].

Finnish investigators discovered that prevalence of food allergies in Helsinki region was $19.0 \%$ among children under age of one year; $27.0 \%$ among three year olds and $8.0 \%$ - among children of six. This shows that food allergy is more common among babies and young children [6].

According to the results of ISAAC (the International Study of Asthma and Allergies in Childhood), allergy symptoms are more prevailing in Western Europe in comparison to non-polluted rural areas and former Social states in Central and Eastern Europe and Finland, including industrial cities in Poland, Estonia and Russia [7]. The investigators estimated that the prevalence of food allergies in the USA was 4.0\% [8]; in the European Union - 35\% [9]; in the United Kingdom - 20\% [10].

In conclusion, after analysing many studies, performed in various places, it could be stated that the prevalence of food allergies differs in many regions. The prevalence is also proved to differ by age - food allergies are more common among babies and young children. Therefore, any comparisons of the rates of this disease among different countries and even cities should be done in a very critical way, considering the age groups, common food and the prevailing ration.

There are not many studies, carried out in Lithuania, to determine the consistent pattern of allergies. There is a lack of information about the prevalence of food allergies and symptoms in various age groups too. By knowing the relevancy of the problem and the fact that this disease is more frequent among children, it is very important to have data about our country, to find out what the situation in different places is and to compare it with other countries. This tackled our aim, objective and the contingent of research. The prevalence of allergies differs in the same country's cities and towns; we explored the prevalence of food allergies among children of primary school age in the capital city Vilnius, hosting diverse nationalities with a variety of lifestyles and nutritional habits.

The aim of this research was to evaluate the prevalence and pattern of food allergies among primary schoolchildren in Vilnius.

\section{MATERIALS AND METHODS}

Vilnius University was a partner in the EuroPrevall integrated project - "The prevalence cost and basis of food allergy in Europe", that is an EU-funded multi-disciplinary research study. By implementing this project in Lithuania, a community based survey among school-age children groups was performed.

The approval of the Lithuanian Bioethics Committee (2005-12-21, No. 60) was given to conduct this biomedical research and the agreement of the Department of Education, Culture and Sport of Vilnius city municipality administration was also obtained. A special questionnaire, created and approved for this project by the Institute of Food Research (Norwich, UK) was used in all participating countries. To ensure the integrity of the study and data, standardised translation procedures, involving a forward and backward translation (from English to Lithuanian), comparison, necessary editing and local piloting were performed. Children filled the questionnaires at home with a help of parents. Parents were earlier informed about the study and the questionnaire and could freely decide upon their participation.

Thirteen primary schools took part in the study with the total number of 190 classes and 4333 schoolchildren in them. 4333 questionnaires were distributed and 3084 (response rate $-71.2 \%$ ) responses were gathered in return.

Statistical data analysis was performed by statistical packages SPSS 17.0 and WinPEPI 11.1, using traditional statistical methods. The prevalence of self reported adverse reactions to food was expressed in percentage. The 95 percent confidence intervals (CI) were chosen. The $\chi^{2}$ criterion, $d f$ (number of the degrees of freedom) and Fisher's exact test were applied for categorical data analysis. The results were considered as statistically significant if the $p$ value was $<0.05$.

\section{RESULTS}

A total number of 30841 st to 4 th grade schoolchildren were examined: 1553 (50.4\%) girls and 1531 (49.6\%) boys responded to the questions. The age of the respondents ranged from 5 to 12 years, the average age was $8.2 \pm 1.2$ years.

$1445(46.9 \%)$ of all respondents have answered positively to the question, if they ever had an illness or trouble caused by eating a food or foods. Hence, we can state that almost half of primary schoolchildren in Vilnius reported health problems caused by eating certain food. Boys and girls ( $48.1 \%$ and $45.6 \%$, respectively) similarly had an illness or a trouble caused by eating (Table 1). After analyzing the distribution of these children according to age, we determined that among those who had a trouble from food, mostly were children of 9 years old (26.8\%), 7 years 
old - similarly (26.0\%), 8 and 10 years old - a little bit less (22.2 and $19.6 \%$, respectively). Children of other age $(5,6$, 11,12 years) had a trouble from food $(<5 \%)$, although there were less of them in the total response group (Table 2).

Besides this question, we asked the participants to answer if they had ever been told by a doctor that the child had a food allergy. $16.4 \%$ of all children reported that they were diagnosed a food allergy. Boys had a diagnosis of food allergy more frequently than girls (18.1 and $14.8 \%$, respectively; $\mathrm{p}=0.014)$ (Table 3).

Allergic reactions, provoked by food, can cause a variety of symptoms, such as, disorders of gastrointestinal tract, respiratory system and skin. The most common trouble or illness, from which the children suffered, was diarrhoea or vomiting (other than food poisoning) (48.0\%); rash, nettle sting like rash or itchy skin were also rather frequent troubles (46.4\%). Moreover, quite often children complained of a headache and a runny or stuffy nose. Difficulty in swallowing, fainting or dizziness and stiffness in joints were rather uncommon symptoms. The distribution of symptoms is shown in Fig. 1. After analyzing symptoms by gender, there was no significant difference - both, boys and girls, most often suffered from diarrhoea or vomiting as well as from skin symptoms such as rash, nettle sting like rash or itchy skin. However, red, sore or running eyes was a symptom twice more often found among boys (8.6\%) than girls (4.1\%) (Table 4).

We also asked to point out how often a child had an illness or trouble after eating food. $46.0 \%$ of children reported having a trouble (of those who had) only once in a lifetime. $32.0 \%$ of them experienced illness or trouble after eating food 2-4 times in a lifetime. $22.0 \%$ of schoolchildren pointed out that quite often felt sick after eating a food or foods. These results did not differ by gender $(\mathrm{p}>0.05)$.

After analysing the food products, which most often caused problems, we found out that these were fruits (24.6\%). In most cases, it was citruses $-7.8 \%$. The second most frequent problematic food (19.4\%) was cow's milk (and other dairy products, including butter, cheese, and yoghurt). 10.9\% of schoolchildren could not eat chocolate, $7.4 \%$ - did not tolerate eggs. Moreover, many pupils pointed out an allergy to vegetables (6.9\%), fish (5.9\%) and nuts (4.8\%) (Fig. 2).

Table 1. Distribution of schoolchildren who had an illness or a trouble, caused by eating a food or foods, by gender

\begin{tabular}{|c|c|c|c|c|c|c|c|c|}
\hline \multirow{2}{*}{$\begin{array}{l}\text { Had an illness or } \\
\text { a trouble, caused by } \\
\text { eating a food or foods }\end{array}$} & \multicolumn{3}{|c|}{$\begin{array}{c}\text { Boys } \\
(n=1531)\end{array}$} & \multicolumn{3}{|c|}{$\begin{array}{c}\text { Girls } \\
(n=1553)\end{array}$} & \multirow[t]{2}{*}{$x^{2}$} & \multirow[t]{2}{*}{ p } \\
\hline & $\mathbf{n}$ & $\%$ & $95 \% \mathrm{Cl}$ & $n$ & $\%$ & 95\% PI & & \\
\hline Yes $(n=1445)$ & 737 & 48.1 & $45.6-50.7$ & 708 & 45.6 & $43.0-48.1$ & \multirow{2}{*}{2.012} & \multirow{2}{*}{0.156} \\
\hline No $(n=1639)$ & 794 & 51.9 & $49.3-54.4$ & 845 & 54.4 & $51.9-56.9$ & & \\
\hline
\end{tabular}

Table 2. Distribution of schoolchildren who had an illness or a trouble, caused by eating a food or foods, by age

\begin{tabular}{|c|c|c|c|c|c|c|}
\hline \multirow{2}{*}{$\begin{array}{c}\text { Age } \\
\text { (years) }\end{array}$} & \multirow[t]{2}{*}{ N } & \multicolumn{3}{|c|}{$\begin{array}{l}\text { Had an illness or a trouble, caused by eating a food } \\
\text { or foods ( } n=1445)\end{array}$} & \multicolumn{2}{|c|}{$\begin{array}{l}\text { Part of schoolchildren who had an illness or a trou- } \\
\text { ble, caused by eating a food or foods in that age }\end{array}$} \\
\hline & & $\mathbf{n}$ & $\%$ & $95 \% \mathrm{Cl}$ & $\%$ & $95 \% \mathrm{Cl}$ \\
\hline 5 & 4 & 2 & 0.1 & $0.02-0.5$ & 50.0 & $6.8-93.2$ \\
\hline 6 & 193 & 70 & 4.8 & $3.8-6.1$ & 36.3 & $29.5-43.5$ \\
\hline 7 & 888 & 375 & 26.0 & $23.7-28.3$ & 42.4 & $39.0-45.6$ \\
\hline 8 & 692 & 321 & 22.2 & $20.1-24.5$ & 46.4 & $42.6-50.2$ \\
\hline 9 & 746 & 387 & 26.8 & $24.5-29.2$ & 51.9 & $48.2-55.5$ \\
\hline 10 & 546 & 283 & 19.6 & $17.8-21.7$ & 51.8 & $47.6-56.1$ \\
\hline 11 & 12 & 6 & 0.4 & $0.2-0.9$ & 50.0 & $21.1-78.9$ \\
\hline 12 & 3 & 1 & 0.1 & $0.002-0.4$ & 33.3 & $0.8-90.6$ \\
\hline Total & 3084 & 1445 & 100 & - & - & - \\
\hline
\end{tabular}

$X^{2}=1375.9 ; \mathrm{df}=7 ; \mathrm{p}<0.001$

$X^{2}=29.6 ; \mathrm{df}=7 ; p<0.001$

Table 3. Distribution of schoolchildren with diagnosed food allergy by gender

\begin{tabular}{|c|c|c|c|c|c|c|c|c|}
\hline \multirow[t]{2}{*}{ Diagnosis } & \multicolumn{3}{|c|}{$\begin{array}{c}\text { Boys } \\
(n=1531)\end{array}$} & \multicolumn{3}{|c|}{$\begin{array}{c}\text { Girls } \\
(n=1553)\end{array}$} & \multirow[t]{2}{*}{$x^{2}$} & \multirow[t]{2}{*}{ p } \\
\hline & $\mathbf{n}$ & $\%$ & $95 \% \mathrm{Cl}$ & $\mathbf{n}$ & $\%$ & $95 \% \mathrm{Cl}$ & & \\
\hline $\begin{array}{l}\text { Food allergy was diagnosed } \\
\qquad(\mathrm{n}=505)\end{array}$ & 276 & 18.1 & $16.1-20.1$ & 229 & 14.8 & $13.0-16.7$ & \multirow{2}{*}{6.064} & \multirow{2}{*}{0.014} \\
\hline $\begin{array}{l}\text { Food allergy was not diagnosed } \\
\qquad(\mathrm{n}=2579)\end{array}$ & 1255 & 81.9 & $80.0-83.9$ & 1324 & 85.2 & $83.4-87.0$ & & \\
\hline
\end{tabular}




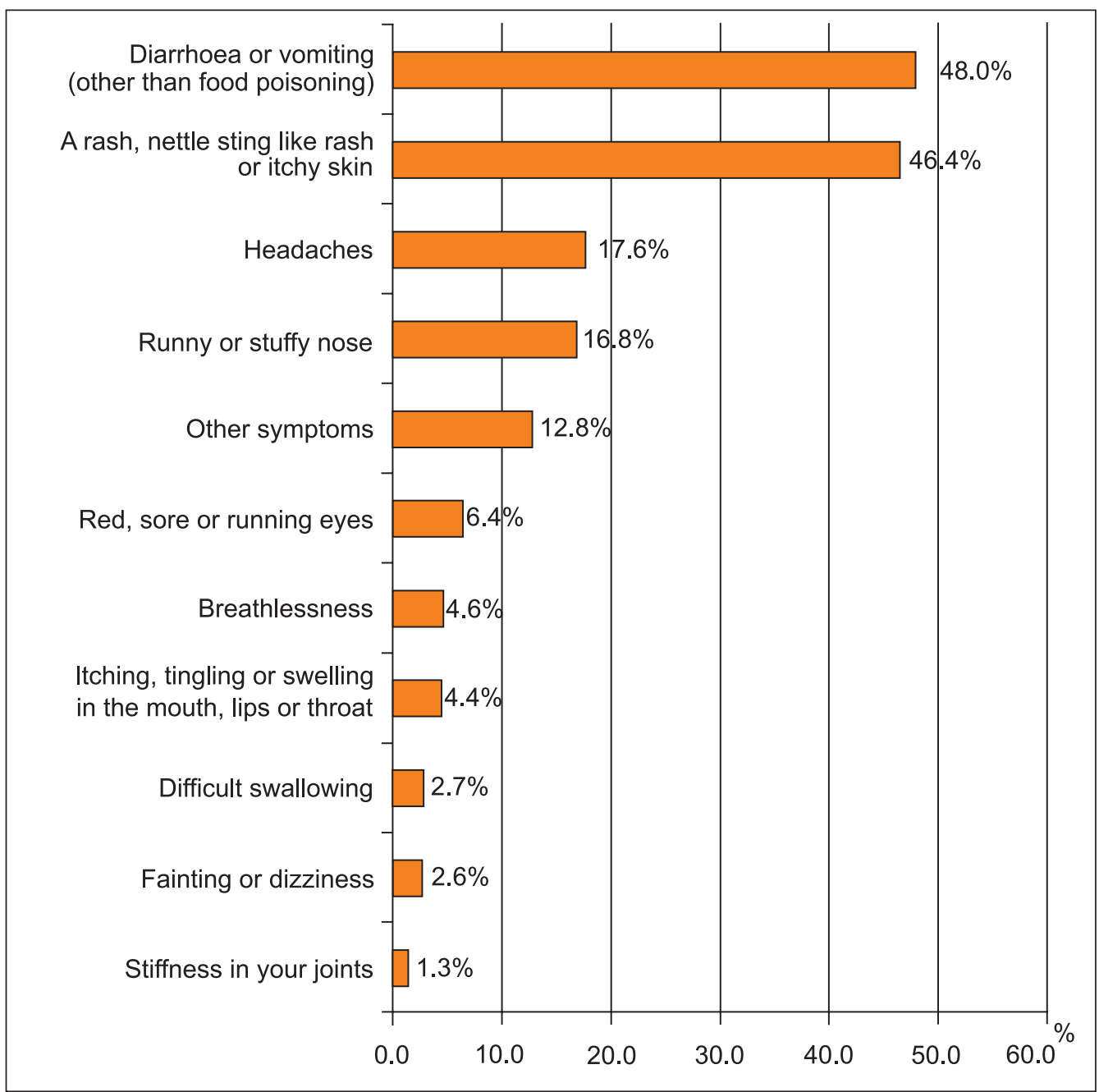

Fig. 1. Distribution of symptoms among children that had a trouble from food

Table 4. Distribution of symptoms among schoolchildren by gender

\begin{tabular}{|c|c|c|c|c|c|c|c|c|}
\hline \multirow[t]{2}{*}{ Ailments } & \multicolumn{3}{|c|}{$\begin{array}{c}\text { Boys } \\
(n=737)\end{array}$} & \multicolumn{3}{|c|}{$\begin{array}{c}\text { Girls } \\
(n=708)\end{array}$} & \multirow[t]{2}{*}{$x^{2}$} & \multirow[t]{2}{*}{$\mathbf{p}$} \\
\hline & $\mathbf{n}$ & $\%$ & $95 \% \mathrm{Cl}$ & $\mathrm{n}$ & $\%$ & $95 \% \mathrm{Cl}$ & & \\
\hline $\begin{array}{l}\text { Diarrhoea or vomiting } \\
\text { (other than food poisoning) } \\
\text { ( } n=694)\end{array}$ & 348 & 47.2 & $43.6-50.9$ & 346 & 48.9 & $45.1-52.6$ & 0.395 & 0.53 \\
\hline $\begin{array}{l}\text { A rash, nettle sting like rash } \\
\text { or itchy skin }(n=671)\end{array}$ & 354 & 48.0 & $44.4-51.7$ & 317 & 44.8 & $41.1-48.5$ & 1.542 & 0.214 \\
\hline Headaches $(n=255)$ & 117 & 15.9 & $13.3-18.7$ & 138 & 19.5 & $16.6-22.6$ & 3.25 & 0.071 \\
\hline $\begin{array}{l}\text { Runny or stuffy nose } \\
(\mathrm{n}=243)\end{array}$ & 135 & 18.3 & $15.6-21.3$ & 108 & 15.3 & $12.7-18.1$ & 2.422 & 0.12 \\
\hline Other $(n=185)$ & 98 & 13.3 & $10.9-16.0$ & 87 & 12.3 & $10.0-14.9$ & 0.329 & 0.566 \\
\hline $\begin{array}{l}\text { Red, sore or running eyes } \\
(\mathrm{n}=92)\end{array}$ & 63 & 8.6 & $6.6-10.8$ & 29 & 4.1 & $2.8-5.8$ & 12.007 & $<0.001$ \\
\hline Breathlessness $(n=66)$ & 40 & 5.4 & $3.9-7.3$ & 26 & 3.7 & $2.4-5.3$ & 2.552 & 0.11 \\
\hline $\begin{array}{l}\text { Itching. tingling or swelling } \\
\text { in the mouth. lips or } \\
\text { throat }(n=64)\end{array}$ & 31 & 4.2 & $2.9-5.9$ & 33 & 4.7 & $3.2-6.5$ & 0.176 & 0.674 \\
\hline Difficulty swallowing $(n=39)$ & 22 & 3.0 & $1.9-4.5$ & 17 & 2.4 & $1.4-3.8$ & 0.469 & 0.494 \\
\hline Fainting or dizziness $(n=37)$ & 19 & 2.6 & $1.6-4.0$ & 18 & 2.5 & $1.5-3.8$ & 0.002 & 0.966 \\
\hline Stiffness in joints $(n=19)$ & 11 & 1.5 & $0.8-2.5$ & 8 & 1.1 & $0.5-2.0$ & 0.366 & 0.545 \\
\hline
\end{tabular}




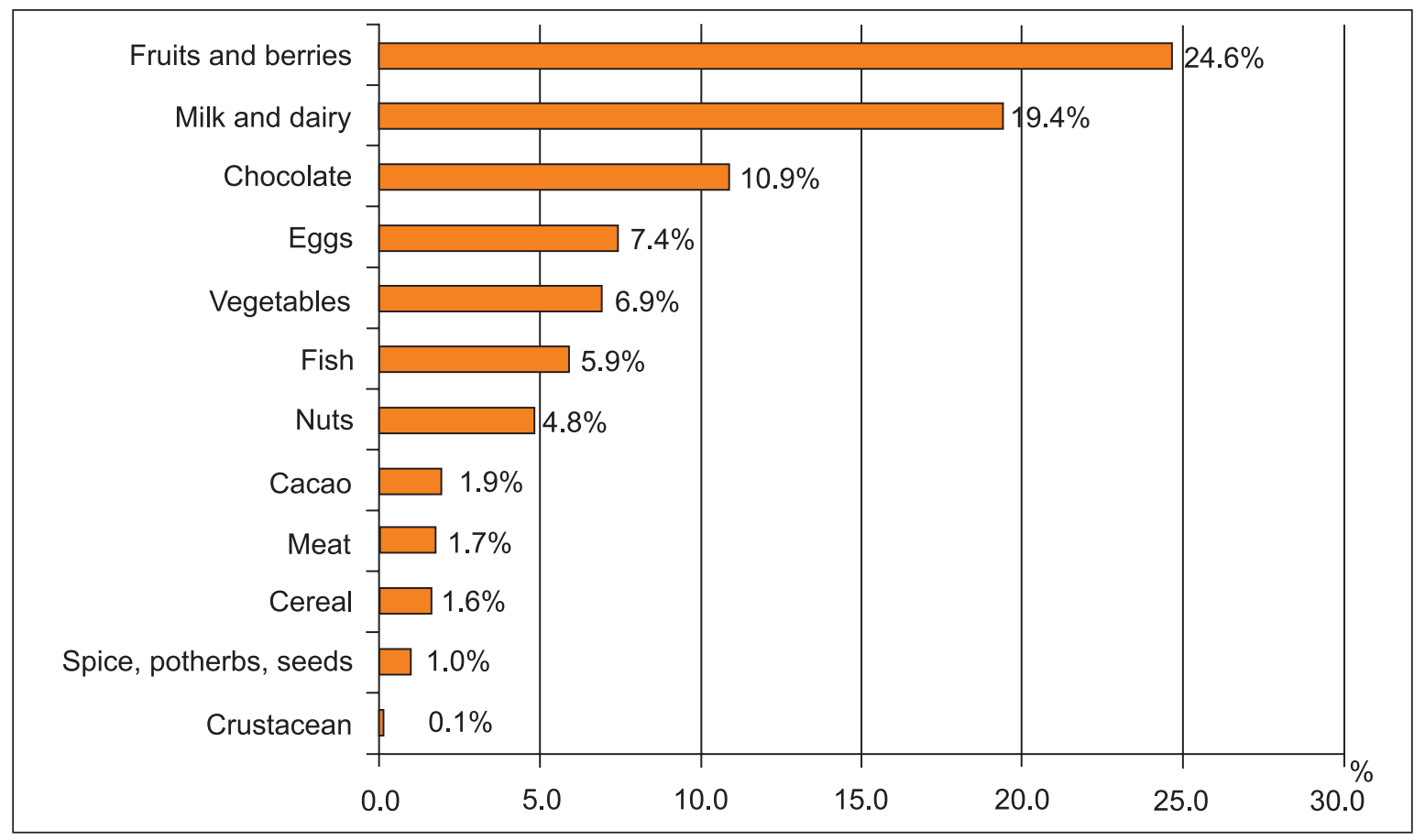

Fig. 2. Distribution of foods that caused clinical symptoms to children

\section{DISCUSSION}

According to our data, almost half of the children from the primary schools in Vilnius, who were interrogated, had an illness or trouble caused by eating a food or foods. These troubles were assessed as food allergy symptoms. Prevalence of food allergy is different in the world; according to various studies, from 3 to 35 percent of population suffer from this disease [11].

There was no significant difference in the prevalence of self-reported adverse reactions to foods between boys and girls. This finding is in accordance with the results of another similar Lithuanian study, carried out on food allergies among children in Vilnius [12].

It is known that the prevalence of food allergies depends on age. These diseases are more prevalent among babies and young children. However, significant differences between similar age groups, e. g., children of 0-5 years, were not found [11]. When comparing children under investigation by age, the data were much the same - the biggest number of children that had trouble from food was found in the 9-year olds group; a smaller part among 7, 8 and 10year olds and even less in another age groups.

It is important to mention that an illness or trouble caused by eating a food or foods can be not only a symptom of food allergy, but also caused by food intoxication. Therefore, we also detected that $16.4 \%$ of children were diagnosed to have a food allergy. The reason of this rather small, in comparison, percentage could be explained by the fact that, probably, not everyone, who has a trouble or ill- ness, goes directly to a doctor or seeks medical aid. It is also very important to know what food one cannot tolerate and try to avoid it - that is a very effective way of "treatment". It accounts for the reason why it is extremely difficult to draw exact conclusions about food allergy prevalence only by analysing outpatient registry and various types of epidemiological research done in the world.

Food allergy causes many various symptoms in childhood; some of them may be unnoticed, while others could be chronic or acute, in rare cases terminating by death [13]. Allergic reactions provoked by food cause a lot of symptoms that mostly include disorders of gastrointestinal tract, respiratory system and skin [14]. In our study, the most common trouble or illness, if a child had such, included diarrhoea or vomiting (48.0\%). Rash, nettle sting like rash or itchy skin was also a frequent trouble $(46.4 \%$ of the respondents indicated this symptom). Comparing our data with other studies, it was detected that half of the children, who had food allergy, suffered from symptoms that manifested in skin, especially rashes; one fifth of our respondents had gastrointestinal symptoms, particularly vomiting, diarrhoea, stomach ache, itching in the lips or palate [10]. According to the data of the other research, performed in Vilnius, where schoolchildren of 10-16 years old were included, 34.8 percent of allergic to food children indicated rash and running or itching eyes; 14.5 percent suffered from breathlessness [12].

Eight main products that often cause food allergy, are noted by recent research data; these are - cow's milk, hen's egg, soya, hazelnut, peanut, wheat, fish and crustacean [15]. 
Cow's milk, hen's egg, fish and nuts are often mentioned in other studies as common food allergens [14; 16-18]. However, it is worth mentioning that the frequency and prevalence of the main food allergens may differ distinctly depending on the geographical peculiarities of the living area. Therefore, foods and their quality differ, for example, peach is a common allergen in the Mediterranean region, while it is not a problematic food in North Europe, and in Lithuania [11]. Definitely, it is conditioned by nutrition and ratio, because people eat food that is commonly-used in the region. The study, aimed to determine the regularities and differences of food intolerance in North European countries, where 1139 food sensitive patients from Sweden, Denmark, Estonia, Lithuania and Russia were analysed, showed that foods, causing troubles, differ between countries. Citrus fruit, chocolate, honey, apple, hazelnut, strawberry, fish, tomato, eggs and milk were noted as common problematic foods in Russia, Estonia and Lithuania, while nut, apple, kiwi, carrot - in Sweden and Denmark. In all countries, children more often than adults had problems with citrus fruit, tomato, milk, strawberry, eggs and fish [19].

Most common food, the prevalence of which is not conditioned by a geographical region, is milk and eggs, due to their specific consistence - both have many proteinsantigens, possessing strong allergic characteristics [20]. As allergies for the specific food depend on the living place and geographical region, explains the fact that Vilnius city schoolchildren in our study, had little problems while eating fish (5.2\%) and nuts (4.7\%) that is not common in such countries as, France, Spain or Italy, where these foods are between the most problematic ones $[14,16,17]$. However, it could be also explained that Lithuanians eat them more rarely. Due to climatic conditions, geographical position and better economic development in those countries nuts and fish are more popular in a daily ratio. While in Lithuania, there are more favourable conditions to grow and eat fruit (apples), berries (strawberries) and vegetables (carrots, tomatoes) that become a common reason of children food allergy.

\section{CONCLUSIONS}

1.46.9\% of children from primary schools in Vilnius had an illness or a trouble, caused by eating a food or foods; boys and girls were similarly affected.

2. Food allergy was diagnosed to $16.4 \%$ of children.

3. The most commonly mentioned trouble or illness, from which children suffered, was diarrhoea or vomiting (other than food poisoning) (48\%). A rash, nettle sting like rash or itchy skin was also a frequent trouble ( $46.4 \%$ of children indicated this symptom). Other common symptoms were headaches and a runny or stuffy nose. Difficulty in swallowing, fainting or dizziness and stiffness in joints were uncommon symptoms.

4. Fruits $(24.6 \%)$ and mostly citrus $(7.8 \%)$ were the most common foods that caused clinical symptoms. Other important problematic foods were milk and dairy products (19.4\%), chocolate (10.9\%), eggs (7.4\%).

\section{ACKNOWLEDGMENTS}

Data from implementing the EuroPrevall - "The prevalence cost and basis of food allergy in Europe", an integrated project, funded by the European Commission under the 6th Framework programme (FOOD-CT-2005-51400) in Lithuania, are presented in this article.

Received 13 June 2011 Accepted 31 August 2011

\section{References}

1. Dubakienè R. Alergologija, ekologija ir visuomenès sveikata. Vilnius, VU 2000: 3.

2. Ferreira CT, Seidman E. Food allergy: a practical update from the gastroenterological viewpoint. J Pediatr (Rio J) 2007; 83(1): 7-20.

3. Kanny G. Food allergy. Rev Prat 2007; 57(12): 1331-8.

4. Sicherer SH, Sampson HA. Food Allergy: Recent Advances in Pathophysiology and Treatment. Annu Rev Med 2009; 60: 261-77.

5. Broberg A, Svensson A, Borres MP, Berg R. Atopic dermatitis in 5-6-year-old Swedish children: cumulative incidence, point prevalence, and severity scoring. Allergy 2000; 55: 1025-9.

6. Kajossari M. Food allergy in Finish children aged 1 to 6 years. Acta Paediatr 1982: 71(5).

7. Bjorksten B. The environmental influence on childhood asthma. Allergy 1999; 54(49): 17-23.

8. Sampson HA. Update on food allergy. J Allergy Clin Immunol 2004; 113(5): 805-20.

9. Bartra J, Mullol J, del Cuvillo A, Dávila I, Ferrer M, Jáuregui I, Montoro J, Sastre J, Valero A. Air pollution and allergens. J Invest Allerg Clin 2007; 17(2): 3-8.

10. Young E, Stoneham MD, Petruckevitch A, Barton J, Rona R. A population study of food intolerance. Lancet 1994; 343: 1127-30.

11. Miles S, Fordham R, Mills C, Valovirta E, Mugford M. A framework for measuring costs to society of IgE-mediated food allergy. Allergy 2005; 60(8): 996-1003.

12. Dubakienè R, Šurkienè G, Stukas R, Pirmaitytè-Vilesko J, Kavaliūnas A. Food allergies among 5th-9th grade schoolchildren in Vilnius (Lithuania). Ekologija 2008; 54(1): 1-4. 
13. Furcolo G, Marziali M, Businco L. Food allergy: recent findings. Pediatr Med Chir 1996; 18(6): 551-7.

14. Vigi V, Fanaro S. Food allergies in early childhood. General concepts, etiopathogenesis, and main clinical features. Minerva Pediatr 2000; 52(4): 215-25.

15. Berni Canani R, Ruotolo S, Discepolo V, Troncone R. The diagnosis of food allergy in children. Curr Opin Pediatr 2008; 20(5): 584-9.

16. Rance F, Grandmottet X, Grandjean H. Prevalence and main characteristics of school children diagnosed with food allergies in France. Clin Exp Allergy 2005; 35(2): 167-72.

17. Crespo JF, Pascual C, Burks AW, Helm RM, Esteban MM. Frequency of food allergy in a pediatric population from Spain. Pediatr Allergy Immunol 1995; 6(1): 39-43.

18. Rona RJ, Keil T, Summers C, Gislason D, Zuidmeer L, Sodergren E, Sigurveig T, Sigurdardottir Lindner T, Goldhahn K, Dahlstrom J, McBride D, Madsen C. The prevalence of food allergy: A meta-analysis. J Allergy Clin Immunol 2007; 120(3): 638-46.

19. Eriksson NE, Möller C, Werner S, Magnusson J, Bengtsson U, Zolubas M. Self-reported food hypersensitivity in Sweden, Denmark, Estonia, Lithuania, and Russia. J Investig Allergol Clin Immunol 2004, 14(1): 70-9.

20. Dubakienè R. Alergologija (pagrindai). Vilnius, 2002: 73-6.

Andrius Kavaliūnas, Genė Šurkienė, Rūta Dubakienè, Kęstutis Žagminas, Rimantas Stukas

\section{ALERGIJŲ MAISTUI PAPLITIMAS TARP VILNIAUS MIESTO PRADINIŲ MOKYKLŲ MOKINIŲ}

\section{Santrauka}

Darbo tikslas - įvertinti alergijų maistui ir jų simptomų paplitimą tarp Vilniaus miesto pradinių mokyklų mokinių.

Metodika. Anonimine anketa buvo apklausti 4333 Vilniaus miesto pradinių mokyklų 1-4 klasių mokiniai, gautos 3084 užpildytos anketos. Duomenys analizuoti naudojantis statistiniu paketu SPSS 16.0 ir WinPepi 9.4 ir pritaikant tradicinius statistinius metodus. Alergijų maistui paplitimas išreiškiamas procentais, įvertinant ịverčio tikslumą apskaičiuoti $95 \%$ pasikliautieji intervalai, kategorinių duomenų analizei panaudotas $\chi^{2}$ kvadrato metodas ir Fisher tikslusis metodas. Taikytas statistinio reikšmingumo lygmuo $a=0,05$, kai statistiškai reikšmingas skirtumas $-p<0,05$.

Rezultatai. 46,9 \% Vilniaus miesto 6-12 metų vaikų turi ar yra turejję sveikatos problemų dèl suvalgyto maisto; 16,4 \% vaikų alergiją maistui nustatė gydytojas. Palyginus mūsų tirtus vaikus, pažymëjusius, kad turi problemų dèl suvalgyto maisto, duomenys priklausomai nuo amžiaus buvo panašūs: daugiausia buvo 9 metų vaikų - 26,8 \%,7-mečių, 8-mečių ir 10-mečių buvo kiek mažiau - atitinkamai 26,0 \%,22,2 \% ir 19,6\%. Dažniausiai minimi simptomai buvo viduriavimas ar vėmimas (48,0\%), taip pat odos berimas, tinimas ar niežulys (46,4\%). Pakankamai dažnai vaikai skundèsi galvos skausmais (17,6\%), sloga ar užguluta nosimi (16,8 \%), raudonomis, skausmingomis ar ašarojančiomis akimis $(6,4 \%)$. Dažniausiai įvairius klinikinius simptomus vaikams sukelia vaisiai (24,6\%), iš jų daugiausia citrusiniai (7,8 \%). 19,4\% vaikų negali vartoti pieno ir jo produktų, 10,9 \% - šokolado, 7,4 \% netoleruoja kiaušinių.

Išvados. Mūsų tyrimo duomenimis, alergija maistui yra svarbi Vilniaus miesto moksleivių problema. Būtina tęsti alergijų tyrimus, kad būtų atrasta naujų duomenų, padèsiančių sukurti efektyvias alergijos maistui valdymo priemones, kuriomis galès pasinaudoti tiek politikai, įstatymų leidejjai, tiek medicinos personalas bei patys sergantieji.

Raktažodžiai: padidejęęs jautrumas maisto produktams, alergija maistui, paplitimas, mokiniai 